DOI https://doi.org/10.30525/978-9934-26-075-9-37

\title{
MORPHOLOGICAL FEATURES OF THE ARTERIES OF THE BRAINSTEM OF THE HUMAN AT A MATURE AGE
}

\author{
Lyutenko M. A. \\ Assistant at the Department of Human Anatomy \\ Kharkiv National Medical University \\ Vovk O. Yu. \\ Doctor of Medical Sciences, Professor, \\ Head of the Department of Human Anatomy \\ Kharkiv National Medical University

\begin{abstract}
Zharova N. V.
Candidate of Medical Sciences, Associate Professor at the Department of Human Anatomy

Kharkiv National Medical University
\end{abstract} \\ Gubar V. O. \\ second-year student \\ Kharkiv National Medical University \\ Kharkiv, Ukraine
}

A lot of data on the arteries of the human brainstem have been published in literature in recent years. Most of them concern the sources of its blood supply. Analysis of the literature data shows us that the extraorgan part of the arteries of the human brainstem have been studied quite enough. The issue of branching arteries of the second and third order is still controversial. As for the age characteristics of the arteries, we also did not find enough literature data. As objects of research in this work, we used 54 preparations of the brainstem with arteries of people of different sexes and mature age who died not from pathologies associated with cerebral vessels. Preparations were from the cadaveric material of the Department of Human Anatomy of the Kharkiv National Medical University.

Materials and methods. To identify the sources of blood supply, we carried out the following research methods: macroscopic, macromicroscopic - the method of V.P. Vorobiev. Measurements of the arteries were carried out using a measuring divider and an MBS-2 binocular magnifier with a wide-field 
eyepiece for a binocular loupe, which magnifies the image constructed by the objective up to 20 times - SIGETA WF 20x/10 mm, and a Digital caliper. Acrylic latex (3060 LBS, SYNTHOS DWORY) tinted red (Pigment-Mix, INCHEM) was injected into the arteries. Filling of the arteries with latex was carried out with disposable $2 \mathrm{ml}$ syringes through a KD-FIX catheter, G18 $1.3 \times 45 \mathrm{~mm}$, which was preliminarily fixed with a ligature. After that, the preparations were fixed in a $10 \%$ formalin solution until compaction. After fixation the brainstem was examined under a magnifying glass. Slices of various thicknesses (up to $1 \mathrm{~mm}$ ) were made from it and were further examined using the enlightenment technique and under a low magnification microscope (7X10).

Research results. The branches of the vertebral, main, anterior and posterior spinal and posterior cerebellar arteries - branches of the first, second and third orders - are distributed within the reticular substance of the medulla oblongata. Small arteries form numerous anastomoses among themselves, forming a dense arterial net. Along the entire length of the medulla of the brainstem, there are areas of relatively higher concentration of arterial vessels, which correspond to the locations of the various nuclei of the cerebral nerves. Each of these sites includes from 3 to 10 branches of the 3-4th order. These small arteries form nets of varying degrees of density and are located in the areas where the nuclei of the cerebral nerves are located.

The general direction of the arteries and arterial anastomoses reflects not only the internal structure, but also the shape of various parts of the brainstem in the form of elongated ovals and polygons. In the area of the pons, 6-12 branches depart from the main and superior cerebellar arteries that supply blood to the area of the auditory fields, 5-7 arteries to the area of the facial mounds and 3-5 arteries to the area of the trigeminal nerve nuclei. In the area of the trapezoidal body of the pons, the arteries are directed along its fibers, and are connected to each other in the form of straight, oblique, arcuate, and strongly branching anastomoses.

The midbrain is supplied with blood by arteries running in the longitudinal direction. In the area of the red nucleus, the number of arteries ranges from 6 to 11 . They branch off from the middle, medial and lateral group of midbrain arteries, branch at different angles and form numerous connections and extensive nets. Distinctly identifiable nets of arteries are also located in the central substance around the Sylvian aqueduct. In the tubercles of the quadruple arteries branch first fan-shaped, then in different directions. The greatest number of arteries originating from various sources supplying the human midbrain rushes to the optic tubercle. It receives blood supply from 
both the ventral and dorsal sides. The ramifications of these arteries form small-looped nets of arterial anastomoses that penetrate into the substance of the optic tubercle. In addition, in the thalamus there are straight and slightly arcuate connections between large vessels, entering the optic tubercle from opposite sides.

In a person over 60 years old, the arteries of the brainstem are bent and partly change their orientation in comparison with a younger age. This is due to the general phenomena of aging of the vascular system.

Summary. So, on the base of our studies, we can conclude that part of the arterial anastomoses, both between individual arteries and between arterial networks, branches along their course, creating multiple network plexuses between themselves. Therefore, the arterial bed of the human brain stem in most areas (especially in the midbrain and diencephalon) can be characterized as a continuous arterial network, not divided into distinct zones. The significant development of the arteries of the brainstem can be explained, apparently, by the maximum development in a person of the brainstem itself, which receives arterial blood supply from a greater number of sources, as indicated by both literary and our own data. It is also associated with the growth and development of the terminal brain and the influence on the trunk of the cerebral cortex.

\section{References:}

1. Хейнс Д. Нейроанатомия: атлас структур,срезов и систем / Д. Хейнс. - Москва: Логосфера,2008. - 344 с.

2. Cardin V. Sensitivity of human visual and vestibularcortical regions to egomotion-compatible visualstimulation / V. Cardin, A.T. Smith // Cereb.

3. Cortex. -2010. - Vol. 20, N 8. - P. 1964-1973.Johnson C.L. Local mechanical properties of white matter structures in the human brain / C.L. Johnson, D. McGarry, A.A. Gharibans [et al.] // Neuroimage.- 2013. Vol. 79. - P. 145-152.

4. Пат. № 52432, UA, МПК А61B 5/04 / Харківський національний медичний університет, Степаненко О.Ю. - 3. № u201002490; Заявл. 05.03.2010; Опубл.

5. 25.08.2010. Спосіб визначення зони васкуляризації структур головного мозку.Фомкина О. А. Прочностные свойства артерий основания головного мозга взрослых людей зрелого возраста / О. А. Фомкина // Известия высших учебныхзаведений. Поволжский регион. Медицинские науки. - 2009. - № 2 (10). - С. 39-43. 
6. Низамов Ф.Х. Функциональные возможности ветвей мозговых артерий в зависимости от типов их ветвления / Ф.Х. Низамов // Медицинская наука и образование Урала. - 2016. - Т. 17. № 1 (85). С. 50-53.

DOI https://doi.org/10.30525/978-9934-26-075-9-38

\title{
СТУПІНЬ ПРОЯВУ ХРОНІЧНОӤ ВТОМИ У СТУДЕНТІВ МОЛОДШИХ КУРСІВ ЗАКЛАДІВ ВИЩОЇ МЕДИЧНОЇ ОСВІТИ 3 РІЗНИМИ РІВНЯМИ ФІЗИЧНОГО ЗДОРОВ'Я В ДИНАМЦЦ НАВЧАЛЬНОГО ПРОЦЕСУ
}

\author{
Тисевич Т. В. \\ асистент кафедри загальної гісієни та екологї \\ Вінницький національний медичний університет імені М. І. Пирогова \\ м. Вінниця, Україна
}

Актуальність. Постійний потік інформації посилює психічну діяльність людини, викликаючи психологічне напруження та перенапруження. На думку психологів, саме таке психологічне перенапруження, в свою чергу, може спровокувати виникнення хронічної втоми. Хронічна втома виникає в осіб незалежно від соціального статусу, освіти та рівня доходів. Вона є синдромом тих, хто багато та сумлінно працює $[1$, с. 6].

Студентський період, особливо на молодших курсах, характеризується формуванням нового стереотипу повсякденної діяльності, необхідністю швидкої адаптації їх організму до незвичного середовища перебування, міжособистісних відношень, найбільшим рівнем функціонального напруження регуляторних систем організму. Тоді, коли ці чинники перевищують поріг студентського сприйняття, виникає психологічне перенапруження і , як наслідок, хронічна втома. При хронічній втомі відмічається не відповідність між витратами енергії організмом та процесами іiі поповнення, що знижує адаптаційні можливості та опірність організму до дії чинників зовнішнього середовища. Наскільки ефективно організм буде чинити опір різним чинникам залежить від його функціональних резервів, основою яких є фізичне здоров’я.

Мета дослідження: визначити ступінь хронічної втоми студентів I курсу закладів вищої медичної освіти в міжсесійний і сесійний періоди та встановити іiї взаємозв'язок з рівнем фізичного здоров'я. 